\title{
RAI UNDER THE CENTER-RIGHT: WITHER 50 YEARS OF PUBLIC SERVICE TELEVISION?
}

\author{
Matthew Hibberd
}

\section{Introduction}

This chapter reviews key Italian media events of 2003, focusing on the political controversies surrounding the Italian public service broadcaster, Radiotelevisione italiana (RAI), and the new broadcasting legislation, the Gasparri law. This new law paves the way for the partial privatization of RAI, which, the government hopes, will mirror the financial success of other privatizations. Media issues relating to new legislation and to the nomination of RAI's Administrative Council created bitter political arguments in 2003. The Berlusconi government defended its handling of RAI matters and the new legislation, arguing that it is promoting a modern and dynamic media industry. Opposition parties claimed, however, that new legislation and the political control of RAI suit Prime Minister Silvio Berlusconi's political and commercial interests and undermine RAI's public service obligations. This essay will examine both sides of the political debate.

This chapter is divided into five sections, including this introduction and the conclusion. The second section provides a brief overview of the structure of public service broadcasting and the television market in Italy. The third section examines political developments affecting RAI since Berlusconi's return to office in May 2001. The fourth 
section outlines details of the new Gasparri law. Despite gaining full parliamentary approval in December 2003, it should be noted that, also in December, President Ciampi refused to sign the Gasparri law, declaring that parts contravened previous judicial decisions and therefore were unconstitutional. The research draws on qualitative methodologies, including the collection of written documentation and in-depth interviews with broadcasters, journalists, and policy-makers.

\section{RAI: Between State and Market}

Television in Italy celebrated its 50th anniversary in January 2004. Throughout that time, RAI has been charged with promoting democratic ideals and practices through the provision of television and radio programming. Despite being poorly resourced compared to its European counterparts, RAI enjoys the highest viewing figures of all major public service broadcasters in Western Europe, providing a wide range of programs available to all. ${ }^{1}$ It also provides minority language programs in the north and is seeking to extend its services to other groups and minorities. In recent years, there has been a revival of drama programming on RAI, and there has also been an upturn in the fortunes of RAI Radio, which, incidentally, celebrates its 80th anniversary in $2004 .^{2}$

The cost of enjoying the highest viewing figures in Europe has been political servitude. Political parties have always asserted great influence and control over RAI. Until 1975, the Christian Democrat-controlled governments made key nominations to RAl's board. After 1975, and until 1993, the Parliamentary Commission for Television and Radio, dominated by the triumvirate of Christian Democrats, Socialists, and Communists, was responsible for nominating RAI's Administrative Council. While the lottizzazione system was dismantled in the post1993 reforms, Italian public service broadcasting remains closely controlled by political parties. With the development of a more adversarial political system in Italy in the post-1994 period, some analysts argue that the continued political domination of RAI equates to a process of "militarization." 3 Unlike the old proportional system under the Christian Democrats, the two new major political alliances, the center-left Olive Tree Alliance and Berlusconi's center-right alliance, have been less willing to carve up the company among all major political forces, opting instead to promote its own supporters to key senior posts within the three television and radio networks, the news services, and, especially, the Administrative Council. And when one alliance loses office, there has usually been a change of key personnel at RAI. 
RAI's position is further complicated by Mediaset's dominant hold over the commercial broadcasting sector and the rise to high political office of the company's major shareholder, Silvio Berlusconi. The broadcasting market in Italy is one of the most concentrated in the world, with RAI and Mediaset together attracting over 90 percent of national audiences and advertising revenues. The rapid growth of the duopoly and Berlusconi's political rise have led more than one commentator to declare that RAI and Mediaset have created, whether intentionally or not, a form of co-dependence over the years. ${ }^{4}$ It has been argued that Mediaset needs RAI to justify having three channels, in this way resisting center-left attempts to reduce this number to two. RAI, so the argument goes, could justify its shift to popular programming over the years by pointing to Mediaset and claiming it was acting in self-defense. In recent years, the development of the two companies has also been linked in judicial decisions and legislative provisions. Most notably, the 1997 broadcasting law linked the fate of Retequattro and Raitre-with the former going to satellite and the latter giving up advertising revenues-in order to loosen the power of the two companies over the Italian broadcasting system.

The dominance of the RAI/Mediaset duopoly has helped ensure the rapid growth of terrestrial television to the detriment of cable and satellite broadcasting. There is no national cable television system in Italy, and satellite television has enjoyed only relative success in recent years with the arrival of French and American players. The high number of terrestrial channels also means that Italy attracts far lower advertising revenues than its main European counterparts (about half the rates of the principal German and UK operators) but as a result has fewer resources to devote to expensive programming. This has led to vociferous criticism about the perceived low quality of some Italian television programs. ${ }^{5}$

\section{RAI under the Center-Right Government, 2001-2003}

I have noted elsewhere that the first Berlusconi government (MarchDecember 1994) stamped its mark on RAI by sacking the old Administrative Council and replacing it with a more supportive and pliable set of administrators. To my mind, this constituted the most shameless attack on the key twin tenets of public service broadcasting: its independence and impartiality. ${ }^{6}$ Just why governments in Italy and elsewhere do this (this has also been a constant feature of center-left governance in Italy-see below) is not difficult to ascertain. In the words of one former president of RAI: "The political thinking is that 
if you want to rule and take strong government action, you'd better have the information media in your hands first." Arguably, on the one hand, there are a number of material benefits that might accrue from controlling state media or media appointments, such as possible favorable news coverage, for example. On the other hand, the assertion of political authority over public institutions such as RAI acts as a symbolic gesture of political party power.

The ironic feature of the first Berlusconi government, though, was that its tough and assertive control over RAI and public service broadcasting did not prevent it (that is, the coalition) from imploding. That Berlusconi controlled three private television channels and other magazines and newspapers, as well as denying the state channels due impartiality and independence, did not save his first government from ignominious collapse after only nine months. And while media policy did not constitute the straw that broke the coalition's back, the reappointment of RAI's Administrative Council and directors of the three news services and channels in July and September 1994 did create major tensions within the Berlusconi coalition, especially with the Northern League.

One would expect, therefore, that this time around the Berlusconi government would take a more cautious approach to RAI, if only to encourage harmonious relations within the coalition. Instead, the past two and a half years have been very stormy for RAI. The company has seen protracted and bitter internal arguments (stoked by external political forces) and an ongoing series of pernicious political attacks that have struck at the very heart of its public remit. These arguments and attacks have centered around the appointment of two Administrative Councils since 2001, each accused of being politically partial, and accusations made by Berlusconi himself against two of RAI's senior journalists, both of whom were subsequently suspended by the company. Italian journalists, as well as foreign commentators and the center-left opposition, have therefore accused the second Berlusconi government of compromising RAI's impartiality and independence. Let us look at these allegations in more detail.

The appointment of RAI's new five-person Administrative Council in February 2002 led to the promotion of senior managers and journalists favored by government coalition parties. Berlusconi himself argued that "new appointments would ensure that RAI provided objective information and abandoned the factionalism that characterized its 'military occupation by the left." 8 Berlusconi's attitude toward RAI followed a pattern similar to that of other Italian governments in promoting supportive managers and journalists to key positions (the so-called process of militarization). One negative aspect of 
such a policy is that skilled professionals within RAI can be often sidelined to marginal posts, especially if perceived as politically "unsound" by government parties. The waste of talent, in terms of both costs and human resources, caused by such political shenanigans is incalculable. It goes without saying that RAI and public service broadcasting suffer most from such a policy.

Berlusconi went beyond the usual political protocol, however, when in May 2002 he singled out veteran journalist Enzo Biagi, political talk show host Michele Santoro, and comedian Daniele Luttazzi, criticizing them for making "criminal use" of RAI at the license-payers' expense. ${ }^{9}$ In his now infamous Sofia declaration (he was on an official visit to Bulgaria when he made these comments), Berlusconi added that he had nothing against their continued appearance, "but since they don't change ..."10 The fact that Berlusconi had singled out these three did not surprise too many commentators. Luttazzi and Biagi were criticized by the center-right in the run-up to the 2001 election. Santoro had also been accused of bias against Berlusconi. The fact that a politician criticized a public service broadcaster and its journalists and presenters is nothing new. It happens in every country. In the UK, for example, there have recently been bitter political arguments between the government and BBC over coverage of the Iraq conflict, culminating in the Hutton inquiry, which was set up in July 2003 to examine the death of government scientist David Kelly (who had been named by the Ministry of Defence as the principal source for the contentious radio report that started the arguments).

But what made the Italian case far more serious was that all of those named by Berlusconi were subsequently suspended from RAI's schedules in autumn 2002. This is despite the fact that Santoro and Biagi were senior RAI journalists fronting popular programs. While the then president of RAI, Antonio Baldassarre, argued weakly that Biagi and Santoro had been dropped due to scheduling considerations, many commentators and politicians (including those in Berlusconi's coalition) were shocked by the episode. The top Mediaset talk show host, Maurizio Costanzo, even quipped that Mediaset was more open to dissenting voices than RAI. Berlusconi was seeking simple revenge against those whom he perceived to be instruments of the center-left and who had been critical of him during the election campaign. This episode, more than any other, clearly demonstrated the degree to which RAI's independence was being compromised. Thanks to plenty of historical precedents, no one should be surprised at this situation. And it is not a condition that afflicts only Italy (as the 2003 Russian elections have ably demonstrated). 
The strength of opposition to the series of events outlined above created a large anti-government consensus by June 2002. Many commentators feared that Berlusconi's full frontal attack on RAI, coupled with new legislation granting senior institutional figures, including himself, immunity from prosecution while in office, undermined vital freedoms in Italy. The concerns of many people within and outside Italy provoked a response from the president of the Republic, Carlo Azeglio Ciampi, in the form of an open letter read to Parliament in July 2002. The contents of the letter included an appeal to respect and adhere to key concepts of pluralism and impartiality, while restating the central importance of the mass media to the democratic process.

There was nothing original in Ciampi's approach. As guardian of the Constitution, he was merely appealing to the parties to abide by those provisions. Ciampi's attempt mirrors exactly the actions of his predecessor, Oscar Luigi Scalfaro, who, during the first Berlusconi government, sent an open letter to Parliament outlining the key concept of Par Condicio: "[I]n recent times, on at least two occasions, I have been obliged to bring to your attention a matter that I consider vital for a democracy, that is, Par Condicio, which must be recognized by all political groups. The principle of Par Condicio gives all political and cultural groups the right to express themselves and to be heard across the broad spectrum of the mass media."

The Ciampi letter was widely interpreted as a coded attack on the Berlusconi government, leading to further political debate. What Ciampi and others grasped is that it is no longer acceptable to ensure pluralism by allowing different political parties to exercise direct power over RAI (lottizzazione). ${ }^{12}$ In the new political era, in which there are two identifiable, if somewhat fluid, political blocs, parties run the risk of fatally compromising essential constitutional and democratic freedoms when they continue to "militarize" public service broadcasting. The events of spring and summer 2002 were merely a prelude to an extraordinary series of events in early 2003 .

From its very outset-and especially after the Sofia declarationthe Administrative Council led by Antonio Baldassarre was split by irreconcilable political differences: two Council members sympathetic to the opposition resigned in the autumn of 2002, saying that the Council was in a state of turmoil. A third member, broadly sympathetic to the government, followed shortly afterwards. This left the final two members of the Administrative Council clinging desperately to the levers of power. Each refused to resign, causing rifts within the government coalition, with some calling for a complete change of guard and others supporting the last two administrators. The Administrative Council was eventually changed in February 2003, when, 
after an aborted attempt to bring in Paolo Mieli, the former editor of the Corriere della Sera, the senior journalist Lucia Annunziata was elected the new president of RAI. Mieli refused the post in part because he did not receive assurances from political elites that the suspended journalists would be reinstated. But while Mieli was considering becoming president of RAI, anti-Semitic graffiti was daubed on the wall outside RAI's Milan headquarters. The graffiti was directed toward Mieli and the Jewish community, raising the ugly specter of racism and painful historical references to fascism. When Mieli officially refused the president's post, the job was offered to another respected senior journalist, Lucia Annunziata. One of Annunziata's first statements spelled out her hope that Michele Santoro and Enzo Biagi would return to RAI, thus attempting to reassert at least a modicum of independence from political pressures. ${ }^{13}$

Other decisions in 2003 have also benefited Berlusconi's centerright political partners. These decisions have, in general, been piecemeal (fulfilling individual party policies). The decision to move Raidue's management and administrative offices to Milan with the strong backing of the Northern League constitutes a key example of this. Historically, RAI has been overly dependent on Rome and has failed to decentralize properly a portion of its programming and administrative functions to reflect contemporary Italian society. ${ }^{14}$ Although all three RAI channels use additional production centers in Milan, Naples, and Turin, Raitre has traditionally provided the regions with public service programs through the provision of regional news services. So the best placed network to decentralize would surely have been Raitre. Instead, Raidue has moved to Milan. Why? Perhaps one reason is that Raidue's new director, Antonio Marano, is a supporter of the Northern League and the former minister of state in the first Berlusconi government. When Marano was appointed to lead Raidue, he used the opportunity, with the help of political backing from the Northern League, to carry out party policy to decentralize RAI. It should be noted that in moving to Milan, Raidue moved to the stronghold of the Northern League as well as the home of Berlusconi's three channels. It does beg the observation that perhaps Raidue should have been moved to one of the other major cities (Naples, Palermo, or Turin, perhaps), thereby promoting Italian polycentric cultural heritage, instead of further encouraging the development of a bipolar media industry in Italy (based in Rome and Milan).

Contrast the regional aspirations of the Northern League with the conservative and nationalist policies of the National Alliance. Minister of Communications and leading Alliance politician Maurizio Gasparri 
has placed great importance on passing new regulations that protect the rights of minors on television and radio, to the general applause of many. ${ }^{15}$ Other key areas of center-right policy for media development in Italy combine the government's desire to promote larger Italian media companies and to part-privatize RAI in accordance with the 1995 referendum decision, while protecting Mediaset from damaging legislative and judicial decisions, as the rest of this chapter will now discuss.

\section{The Gasparri Law and the Privatization of RAI}

Two key pieces of legislation in Italy over the past decade or so have been the broadcasting acts of 1990 and 1997. Both acts contain several measures that purport to support the Italian audio-visual industry. The 1997 broadcasting act, in particular, was geared toward making necessary regulatory preparations for the eventual adoption of digital terrestrial television (by setting up AGCOM). The law also introduced provisions preparing the groundwork for privatizing RAI, which, in turn, would comply with the result of the 1995 referendum, in which the Italian public voted in favor of the partial privatization of RAI. ${ }^{16}$ Finally, the 1997 law also sought to reduce the dominance of the RAI/Mediaset duopoly, which as early as 1994 had been declared unconstitutional by the Constitutional Court. ${ }^{17}$ Berlusconi voted against parts of the 1997 act and fought their implementation, especially those articles relating to Mediaset and Retequattro. It is not surprising, therefore, that Berlusconi would revise or reverse parts of the 1997 act. And in December 2003, the Italian Parliament passed a new media law. The law outlines plans to part-privatize RAI and it also tackles-albeit in a way very different from the 1997 Act-the thorny issue of the RAI/Mediaset duopoly.

The timetable for the privatization of RAI is vague, with the law requiring only that comprehensive plans be submitted to Parliament in 2004. All details of the sell-off have been left to CIPE to formulate, in consultation with relevant authorities. ${ }^{18}$ The law stipulates, however, that no company or individual can control more than 1 percent of shares or form voting blocs with more than 2 percent of shares. These rules are designed to prevent a takeover of the company by a group of small shareholders. Some of the money raised by the partprivatization will be diverted to fund part of the costs of converting to digital, especially in subsidizing set-top boxes and television sets. The new law also outlines other major changes to RAI and the audiovisual sector in Italy, revising current regulations for advertising and 
media concentration and defining key targets for terrestrial digital penetration up through 2007.

Proposed changes include the way that RAI's Administrative Council will be elected post-privatization. Article 20 states that the Council will be enlarged to nine people elected by shareholders for a period of three years (with a possible three-year extension). As an interim measure, until the privatization process is complete, seven of RAI's Administrative Council will be elected by the Parliamentary Commission for Television and Radio and two, including the president, by the minister for economics. Article 15 focuses on ownership and cross-media ownership rules and allows individual companies to control up to 20 percent of the total media market in Italy. The definition of a media market - a purely economic measure known as sistema integrato delle comunicazioni (SIC) - has been greatly expanded to include areas not previously covered by media ownerships rules. As regards to digital, Article 25 accelerates the timetable for RAI to achieve digital terrestrial penetration (overriding measures contained in Law No. 66 of 2001). The new law states that by 1 January 2004, RAI's digital terrestrial signal must reach 50 percent of national territory; this figure rises to 70 percent by 1 January 2005. It is still expected that RAI's digital services will begin in 2004 .

The regulation and support of audio-visual industries contained in the new law encompasses an enormous scope and includes a wide range of measures, which, to a greater or lesser extent, impinge on both economic and cultural objectives. Since it is beyond the scope of this chapter to evaluate all such measures, my aim, instead, is to consider some of the most important ones. Let's take the most controversial issue first. Article 15 will allow Mediaset to retain Retequattro on terrestrial television, while Raitre will no longer be forced to give up advertising, as both companies will fall safely within the 20 percent SIC threshold (outlined above). This overturns provisions contained in the 1997 act and runs against successive Constitutional Court decisions. To ensure that these media ownership rules were passed, the government overturned an opposition amendment passed in April 2003 that set a limit of two channels per each broadcaster. It is little wonder that many legal experts believe that Article 15 is unconstitutional (an opinion that is shared, as we shall see, the president of the Republic).

Evidence suggests that Article 15 will allow Mediaset to expand at a faster rate than its competitors, thus affecting public service broadcasting, pay TV, and newspaper markets in Italy. ${ }^{19}$ Growth in media markets around the world has been driven in recent years by spot and sponsor advertising and pay TV subscriptions, not license fees. 
Relaxation of media and cross-media ownership rules will benefit above all those companies that derive their income primarily from advertising and subscription payments-Mediaset and SKY Italia. For RAI, which still obtains nearly half its income from an index-linked license fee, the risk of falling behind its competitors is a very real one. This will provide more ammunition to Berlusconi's detractors, who believe the new law puts his commercial interests first and those of the industry and public service broadcasting second.

At the same time, the new law helps RAI. Minister Gasparri is correct when he states that without his law, RAI would suffer further financial difficulties. ${ }^{20}$ The law saves Raitre from having to give up advertising totaling $€ 150$ million per annum. The co-dependence or quid pro quo nature of the Italian broadcasting market is highlighted by the law. While the idea of co-dependence outlined earlier is a useful one, there is little doubt that Mediaset stands to gain more from the legislation. The law does not make adequate financial provisions for RAI in meeting the costs of moving to digital. The company needs to purchase extra frequency capacity for digital signals and plan for more channels in order to persuade Italians to buy digital terrestrial. As we have seen, there are welcome provisions to divert funds from the RAI privatization to subsidize set-top boxes, digital TVs, etc., but more funds should be pumped back into the company to allow it to plan better its infra-structural and programming needs in a digital era. Raising RAI's license fee would be one way to do this, and a oneoff digital payment might also help. But neither of these proposals has been given government backing. One is struck by the current lack of preparation on this level for the impending introduction of digital service in Italy. The law does little to change this.

As regards privatization, there are valid reasons why the Berlusconi government might wish to privatize RAI. Privatization would comply with the result of the 1995 referendum. The partial sale of RAI would also raise considerable sums for the Treasury (at a time when Italy's economy is sluggish), some of which could be diverted to the development of digital services. Finally, there are examples of commercial broadcasters that still manage to provide public service programming (ITV in the UK being one example). However, there are potential pitfalls in privatizing RAI's operations, and current legislation arguably raises more questions than it answers. Public service broadcasters are often better placed to provide program formats such as in-depth political coverage or minority programming. ${ }^{21}$ Would a newly privatized RAI provide the level of public service it currently supplies, and if the privatized company suffers major financial setbacks, would the government be able to insist that it fulfill all of these 
services? Public service broadcasting is also better placed than commercial operators to ensure universal service to all citizens. One must ask whether, with the start of digital terrestrial television approaching, a privatized RAI would still have the same obligations or duties to provide universal service available to all in terms of both geography and programming. Again, will safeguards be put in place to ensure that digital television arrives in every village throughout the peninsula? The other disadvantage of these plans is that they are highly controversial and could cause greater instability within the company at this critical time. With digitalization, RAI is about to undergo one of the most crucial and important phases in its history. ${ }^{22}$ So why complicate matters with privatization at the same time? While these concerns have been expressed forcefully, the Italian government has refused to reconsider its goal of introducing private capital to RAI.

Another problem at this point is that no one knows the extent to which the privatization of RAI will remain partial. If a company is sold off piecemeal, it will leave the Treasury (and, by extension, the government) owning a controlling share of the company. This will not solve the major political problems facing the company. And then one must ask whether commercial media companies and other businesses, national and international, will want to invest in a company over which political influence remains so heavy. RAI is a very different company from Enel, and partial privatization will not end its Janus-faced, split personality. With 50 percent financed by the lowest license fee in Europe and 50 percent (and growing) by advertising, the company in recent years has relied more and more on advertising revenues, with consequences for its programming schedules (which have become more commercially oriented, especially in prime time) and public service remit.

One feature that emerges from an analysis of Italy's broadcasting policy in recent years is that there are strong lines of continuity. Political control over RAI continues unabated, and issues surrounding conflicts of interest remain largely unresolved. What is not in doubt, however, is that Berlusconi has used his parliamentary majority to try to settle the "unfavorable" legislative and judicial judgments surrounding the legal status of the duopoly to his, Mediaset's, and RAI's favor. Protectionism and self-interest overwhelm other components of Berlusconi's media policy. The new media law will result in larger national media companies (especially Mediaset, but also RAI), a common aim of many European governments, but Italy trails wider international trends that have seen governments open up media markets to outside players in response to ideological and technological changes. 
The Gasparri law was passed by the Italian Parliament in November 2003 and sent to the president of the Republic's office for presidential assent. What normally constitutes a procedural formality (the presidential signature on all new acts) was turned on its head when, on 15 December 2003, President Ciampi refused to sign the Gasparri law, declaring that parts (primarily Article 15) contravened Constitutional Court decisions (see note 17 in this chapter for further discussion of these decisions) ${ }^{23}$ While many commentators did not expect or foresee Ciampi's decision, it is consistent with his past (albeit more coded) pronouncements, such as his open letter to Parliament in July 2002. Rather than leave the matter to the Constitutional Court, the head of state intervened directly, and the law was sent back to the Italian Parliament for further consideration.

Ciampi's decision led to a temporary stand off between two broad and fluid camps. One camp, composed of Ciampi, the Constitutional Court, the main regulator AGCOM (which has criticized the Mediaset/RAI duopoly for the past three years, stating that it helps creates an unequal marketplace), and the center-left opposition, has criticized the duopoly and/or the Gasparri law. The other camp, consisting of the government, Parliament (the main organ of public opinion), and Mediaset, has staunchly defended the legislation. The standoff did not last for long, however. In order to beat the Constitutional Court's imposed deadline of 31 December, the government launched the "Salva Retequattro" decree, which allowed Retequattro to broadcast beyond the end-of-year deadline. Berlusconi's supporters hailed the decree as support for the parliamentary law. Opposition politicians decried it as an illegal act that ran contrary to constitutional provisions. In his traditional New Year's Eve speech, President Ciampi appealed for political dialogue while stressing the need to abide by constitutional provisions. The new media law has resulted in a major clash between different institutions of state, with potentially dangerous ramifications for democratic governance in Italy.

And where does this leave RAI? Until the current impasse has been settled, plans for the RAI privatization remain on hold. Provisions contained in the new law for digital broadcasting are in limbo. At a press conference held on 16 December to mark the start of the 50th and 80th anniversary celebrations for public service television and radio, respectively, the proceedings were somewhat overshadowed by the Ciampi decision. Director General Cattaneo spoke of compulsory redundancies for Raitre if the company lost its advertising revenues for the third channel, and there was little mention of the coming digital age. Outside of the press conference, senior executives immediately began dusting down plans outlined in 1997 for the new Raitre. 


\section{Conclusion}

Anniversaries are appropriate times to reflect on past triumphs and disappointments while looking to future hopes and aspirations. As events outlined above demonstrate, it is difficult to talk about RAI's future in the current political climate with any great confidence or certainty. A deep sense of pessimism pervades much thinking about the future role of RAI and public service broadcasting in Italy. And yet the processes of digitalization and part-privatization will eventually take RAI into a third phase of development (the first two being the monopoly years and commercial competition). Celebration of the two anniversaries should therefore be accompanied with new articulations of the company's role and value to contemporary Italian society. Basic questions we need to ask include: Does Italy need a single public service broadcaster? If so, what should its remit include and exclude?

Currently, the company is badly hampered by political interference and a unique broadcasting market. The so-called militarization of RAI constitutes a major compromise to a key institution trying to promote democratic ideals and principles. In many respects, the fact that RAI's main adversary is the prime minister makes matters worse. Berlusconi has compromised the company's independence in the past two years and has promoted his own company's interests through legislative measures. However, RAI's problems, or those of the Italian media in general, cannot be blamed on one man. After all, Berlusconi was not responsible for the system of lottizzazione, and the center-left has not behaved much better toward RAI when in office. It should also be recognized that RAI has benefited from political interference over the years, allowing the company, for example, to lobby effectively against the Raitre changes.

But the lack of effective safeguards guaranteeing media pluralism, especially in relation to RAI, threatens to undermine democratic ideals and processes. One objective for commentators and political elites is to strengthen statutory and corporate safeguards that allow the company to exercise due independence, impartiality, and objectivity in the provision of television and radio programs, especially news services. But another objective must be to examine ways to strengthen Italy's media market in general. When compared to its major European counterparts, the broadcasting industry in Italy is poor, and the top priority should be to examine ways of promoting it as a whole. This would require finding mechanisms to support all three individual sectors (commercial, public service broadcasting, and pay TV) without weakening any of them. ${ }^{24}$ Too often in the past, Italian legislators have done precisely that. The lack of cable television in Italy and the ongoing frequency issue testify to major past errors. 


\section{Notes}

1. V. Emiliani, Affondate La RAI. Viale Mazzini, Prima e Dopo Berlusconi (Rome: Garzanti, 2002), 231-250.

2. RAI derives 93 percent of its revenue from two sources: a license fee payable by all Italian households and spot and sponsored advertising. The company's total income in 2001 was $€ 4,930$ million. The license fee, which, in 2001, made up 53 percent of RAI's total income, is the lowest in Europe (€93.80 in 2002) and the most widely evaded (21 percent of Italian households failed to pay their license fee in 2001). Between 1994 and 2000, the license fee grew by 2.4 percent annually, compared to a 2.9 percent annual rise in the cost of living.

3. B. Vespa, L'Italia di Berlusconi. L'Italia dei Girotondi (Rome: RAI/Mondatori, 2002), 21.

4. D. Giacalone, La guerra antenne. Televisione, potere e politica. I frutti di non governo (Milan: Sterling and Kupler, 1992), 23-25.

5. G. Valentini, "Nel regno del conflitto d'interessi Mediaset affonda Rai e giornali," La Repubblica, 9 July 2003; T. Jones, The Dark Heart of Italy: Travel through Time and Space across Italy (London: Faber and Faber, 2003).

6. M. Hibberd, "The Reform of Public Service Broadcasting in Italy," Media, Culture and Society 23, no. 2 (2001).

7. Claudio Demattè, "Late Show Special, 'Berlusconi,"” BBCTV, September 1994.

8. J. Hooper, "Berlusconi Strokes New Row in TV Bias," Observer, 13 July 2003.

9. Ibid.

10. Ibid.

11. La Repubblica, 24 November 1994.

12. Jader Jacobelli, personal interview, March 2003.

13. With its independence undermined, the key question for many commentators remains whether Berlusconi has also compromised RAI's impartiality as the result of appointing "sympathetic" news directors and perhaps promoting a disproportionate amount of positive new coverage for himself and his coalition partners. What remains unclear, at present, is whether RAI's news coverage in the post-2002 period (when the news directors were reappointed) has favored Berlusconi and his coalition partners. While some Italian-based writers argue this (P. Ginsborg, Berlusconi [Torino: Einaudi, 2003], 38), the lack of published data prevents any definitive conclusions at this time. Given that there are permanent research institutions monitoring political coverage, this information should be forthcoming.

14. Hibberd, "The Reform of Public Service Broadcasting in Italy"; C. Demattè, "Indirizzi programmatici per il piano di ristrutturazione della RAI," reprinted in Gulliver-mensile politico sulle comunicazioni di massa, October 1993; A. Marano, La tv che verrà. Nuove technologie e federalismo per una riforma del sistema della comunicazione (Rome: Edizioni SEAM, 1995); F. Iseppi, "La via italiana al servizio pubblico,” Problemi dell'Informazione, vol. 23 (September 1998).

15. The party's policy of upholding national interest is best illustrated by the Raiway episode. Prior to the May 2001 election, the center-left government and RAI struck a deal with Crown Castle, a Texan company, to sell Raiway, which manages RAI's transmitters; however, in the post-9/11 climate, the Italian government, led by the National Alliance, pulled out of the deal, citing national interest and thus depriving the company of as much as 500 billion lira. For a full discussion, see Emiliani, Affondate La RAI, 98 and chapter 9. 
16. The 1997 act did not privatize RAI; rather, it required the company to split into RAI Holding, a publicly owned holding company, RAI Spa, and five internal divisions (Article 31). Raiuno and Raidue formed part of one division, with Raitre separated from the other two television channels into a second division. Radio services constituted another division. The specific aim of this reform was to prepare the way for the privatization (partial or full) of RAI Holding and/or one or more of these five divisions, including the company's core public services, Raiuno and Raidue. It goes without saying that with a Berlusconi victory, the center-left plans for the privatization of Raiuno and Raidue were shelved. And yet the partition of RAI into five internal divisions has not been markedly revised or abolished, despite the fact that current plans to privatize the company differ from those proposed by the center-left government and seem ill-fitted to the current structure and organization of the company.

17. Of ongoing concern to legislators and judicial authorities has been the status of the RAI/Mediaset duopoly. One defining moment for the duopoly came in December 1994, when the Constitutional Court entered the debate. The legal argument of the case-brought by the minor national commercial channels Telemontecarlo (now La 7), Rete A, and TeleElefant-concerned the claim that Mediaset's position constituted an oligopoly and a dominant market position and therefore breached the Constitution. The main decision of the Court concerned Article 15 of the 1990 broadcasting law, which lays out the provisions limiting the number of channels owned by any one concessionary to 25 percent of the total number of channels. The Court argued that the ownership of three channels as guaranteed by Article 15 distorted the rules of competition in the broadcasting industry and also constituted the potential risk to fundamental values of free speech, of thought, etc. In the Court's opinion, it was the duty of legislators to stop the formation of a monopoly and instead create a system that allowed the greatest possible access. The Court therefore decided that Article 15 was "incoherent, unreasonable, and unsuitable" (La Repubblica, 7 December 1994). The Court ruled, therefore, that Mediaset should lose one channel. Rather than pass a definitive judgment, the Court granted a period of transition so that new legislation could be introduced. The ball was thus passed back to the politicians to decide on the legislation required. The decision of the Court, although technically against Mediaset only, effectively condemned the duopoly as unconstitutional. It was therefore against this backdrop that the 1997 Broadcasting Act reduced the number of RAI channels allowed to take television spot advertising from three to two. With RAI being reduced to just two advertising channels, the Broadcasting Act also required Mediaset to reduce the number of its terrestrial channels from three to two; Retequattro was withdrawn to become a satellite channel. Taken in unison, these developments fulfilled the demands of the Constitutional Court decision of December 1994. But the 1997 act did not provide a precise timetable for these changes, and both Mediaset and RAI successfully lobbied the government and regulators to delay implementation. Both companies would have lost substantial advertising revenues-in RAI's case the company would have lost $€ 150$ million worth of advertising per annum from Raitre-and found common cause. The argument did not end there, however. In 2001, the Constitutional Court set a new deadline for the implementation of the Retequattro decision. The date set was 
31 December 2003, ensuring that the Berlusconi government would have to pass new media legislation by that time.

18. Comitato Interministeriale per la Programmazione Economica (Interministerial Economic Planning Committee), a government body set up by Law No. 48 of 1967, which has the task of directing national economic planning. It is formally chaired by the prime minister, but is in fact headed by the minister for economic planning (http://www.fr.eurofound.eu.int/emire/ITALY/CIPE-IT.html).

19. Valentini, "Nel regno del conflitto d'interessi Mediaset affonda Rai e giornali."

20. La Repubblica, 4 August 2003.

21. R. Collins, "A Future for Public Service Broadcasting?" Keynote speech given to the "Public Service Broadcasting in a Digital Age" conference, Banff, University of Alberta, 8-10 June 2000, 10.

22. Isimm, Riflessioni sul ddl Gasparri, unpublished report, April 2003; Isimm, Servizio pubblico e pluralismo televisivo nell'era del digitale (Rome, 2003), reports from conference held in Rome from 18-19 November 2002.

23. La Repubblica, 16 December 2003.

24. F. De Vescovi, “TV: omologazione o diversificazione?” Problemi dell'informazione (Bologna: Mulino, 2002). 